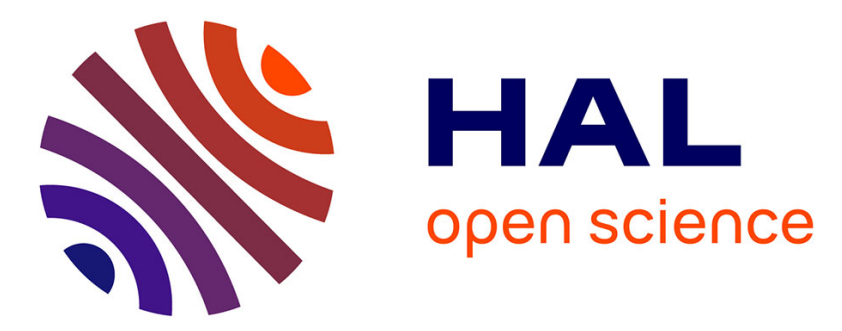

\title{
Hygiene of nasal masks used at home for non-invasive ventilation in children
}

Tiffany Busa, N. Stremler-Le Bel, E. Bosdure, F. Bittar, Jean-Marc Rolain, J.-C. Dubus

\section{- To cite this version:}

Tiffany Busa, N. Stremler-Le Bel, E. Bosdure, F. Bittar, Jean-Marc Rolain, et al.. Hygiene of nasal masks used at home for non-invasive ventilation in children. Journal of Hospital Infection, 2010, 76 (2), pp.187-188. 10.1016/j.jhin.2010.05.005 . hal-01478677

\section{HAL Id: hal-01478677 \\ https://hal-amu.archives-ouvertes.fr/hal-01478677}

Submitted on 6 Oct 2021

HAL is a multi-disciplinary open access archive for the deposit and dissemination of scientific research documents, whether they are published or not. The documents may come from teaching and research institutions in France or abroad, or from public or private research centers.
L'archive ouverte pluridisciplinaire HAL, est destinée au dépôt et à la diffusion de documents scientifiques de niveau recherche, publiés ou non, émanant des établissements d'enseignement et de recherche français ou étrangers, des laboratoires publics ou privés.

\section{(ㅇ)(1) $\$$}

Distributed under a Creative Commons Attribution - NonCommercial - NoDerivatives 44.0 


\section{Hygiene of nasal masks used at home for non-invasive ventilation in children}

T. Busa ${ }^{a}$ N. Stremler-Le Bel ${ }^{\mathrm{a}, \mathrm{b}}$ E., Bosdure ${ }^{\mathrm{a},}$ F. Bittar ${ }^{\mathrm{c},}$ J.-M. Rolain ${ }^{\mathrm{c},}$ J.-C. Dubus ${ }^{\mathrm{a}, \mathrm{b}, \mathrm{c}}$

aUnité de Pneumologie et Médecine Infantile, CHU Timone-Enfants, Marseille, France

${ }^{\mathrm{b}}$ Centre de Ressources et Compétences pour la Mucoviscidose, $\mathrm{CHU}$

Timone-Enfants, Marseille, France

'CURMITE CNRS-IRD UMR 6236, Faculté de Médecine et de Pharmacie,

Marseille, France

\section{Madam,}

Non-invasive ventilation (NIV) is used increasingly in children with chronic respiratory insufficiency. ${ }^{1,2}$ For best results NIV requires a nasal or face mask adapted to the paediatric patient. Other devices used with masks, such as nebulisers in cystic fibrosis (CF) patients or spacer devices in asthmatics, can be microbiologically contaminated. ${ }^{3-6}$ As we found no literature data about contamination of NIV nasal masks, we conducted a pilot study to evaluate the methods of cleaning used by patients at home and their rate of microbial contamination.

Children treated daily with NIV and nasal mask during at least the three previous months were solicited for participating in a study divided into two parts. They first completed a questionnaire concerning the NIV characteristics (indication, date of beginning, frequency of use per day, presence of humidifier), and the maintenance of masks at home (cleaning phases, frequency, disinfectants used, renewal frequency). Second, the interior part of their masks (and, when existing, of the cushion) was rinsed in a standardised way with $10 \mathrm{~mL}$ of sterile $0.9 \%$ saline solution. The washing solution was recovered using a sterile syringe, and collected in a sterile collector tube. A cotton swab was used to clean the interior parts of the mask in contact with the patient. When possible, a microbiological analysis of the sputum was performed. All samples were sent to the laboratory and inoculated on to five agar plates including chocolate Poly ViteX agar, Columbia colistin-nalidixic acid (CNA) agar, MacConkey agar, Cepacia agar, and blood agar. All growth media were purchased from bioMérieux (Marcy l'Etoile, France) and were incubated at $37^{\circ} \mathrm{C}$ for $48 \mathrm{~h}$ except for Cepacia agar that was purchased from AES laboratory (Combourg, France) and incubated at $30^{\circ} \mathrm{C}$ for 5 days. Colonies growing on the various media were identified using standard microbiological methods including Gram-staining, catalase and oxidase activity, API system (bioMérieux), and VITEK 2 Auto system (bioMérieux) and standard procedure for antibiotic susceptibility testing.

Among the 52 patients with NIV followed up, 12 children were included ( 6 boys, mean age 13.3 years; range: 7-19). They were treated for $\mathrm{CF}(N=6)$, spinal amyotrophy $(N=3)$, Duchenne muscular dystrophy $(N=2)$ or achondroplasia $(N=1)$. All $\mathrm{CF}$ patients were chronically infected with various organisms; other patients were usually free from infection. NIV was started at a mean of 34.7 months (range: $3-131$ ), and used 9.8 h per day (range: 6-14). Four NIV apparatus had a humidifier. Nasal masks were replaced two to 12 times per year. The frequency of maskcleaning was variable (mean: 2.9 times per week; range: 0-7). One mask was never cleaned. The others were washed with water and soap (100\%), rinsed with tap water $(100 \%)$, and dried in ambient air (64\%) and/or with absorbent tissue (45\%). Only one mask was disinfected with wipes impregnated with detergent product. Two cultures were positive (16.7\%) (Table I). One mask, belonging to a 17-year-old CF female chronically infected with Staphylococcus aureus and waiting for lung transplantation, was contaminated with $S$. aureus with identical antibiotic susceptibilities to that found in her sputum. The second mask, belonging to an infection free 7-year-old female with spinal amyotrophy, was contaminated with Pseudomonas oryzihabitans. A statistical link between the use of a humidifier and the mask contamination was noted (50\% with a humidifier vs $0 \%$ with no humidifier; $P=0.03$ ).

In our study the masks are not cleaned after each use, and benefit at best from only three of the four recommended steps of cleaning (washing, rinsing, drying after each use; disinfection once a day). ${ }^{7}$ Microbial contamination is less than that described with nebulisers or spacer devices, but reaches up to $16.7 \%{ }^{3-6}$ It is interesting to note that, in CF, the a priori same organism may be found in sputum and NIV nasal mask, suggesting that there should be a systematic change of the whole NIV apparatus when the patient is awaiting lung transplantation to avoid reinfection. To know whether P. oryzihabitans has a pathogenic effect in our patient is difficult because it has only been incriminated in immunocompromised patients, except one immunocompetent patient with bronchiectasis. ${ }^{8}$ Other studies are needed to confirm the link we found between the microbial contamination of NIV nasal masks and the use of a humidifier, but these findings are in accordance with studies on nebulisers, where humidity favours contamination. $^{3}$

In conclusion, nasal masks of NIV are insufficiently disinfected at home. They can be contaminated by different bacteria and may be a source for airway colonisation and/or infection.

Table I

Microbial data from nasal masks and sputum of 12 children treated with long-term non-invasive ventilation (NIV)

\begin{tabular}{|c|c|c|c|c|c|}
\hline Disease & $\begin{array}{l}\text { NIV with a } \\
\text { humidifier }\end{array}$ & $\begin{array}{l}\text { Antibiotics at the } \\
\text { time of the study }\end{array}$ & Liquid rinsing & Cotton swab & Sputum \\
\hline Cystic fibrosis & Yes & Yes & Sterile & Sterile & S. aureus \\
\hline Cystic fibrosis & No & Yes & Sterile & Sterile & S. aureus \\
\hline Cystic fibrosis & No & No & Polymicrobial flora & Sterile & Polymicrobial flora \\
\hline Cystic fibrosis & No & No & Sterile & Sterile & P. aeruginosa \\
\hline Cystic fibrosis & Yes & Yes & Polymicrobial flora & S. aureus & $\begin{array}{c}\text { S. aureus } \\
\text { P. aeruginosa } \\
\text { Candida albicans }\end{array}$ \\
\hline Cystic fibrosis & No & Yes & Sterile & Sterile & Sterile \\
\hline Spinal amyotrophy & Yes & Yes & Polymicrobial flora & P. oryzihabitans & Polymicrobial flora \\
\hline Spinal amyotrophy & Yes & Yes & Sterile & Polymicrobial flora & Polymicrobial flora \\
\hline Spinal amyotrophy & No & Yes & Sterile & Sterile & Not obtained \\
\hline Duchenne disease & No & Yes & Polymicrobial flora & Polymicrobial flora & Not obtained \\
\hline Duchenne disease & No & No & Polymicrobial flora & Polymicrobial flora & Not obtained \\
\hline Achondroplasia & No & No & Sterile & Sterile & Not obtained \\
\hline
\end{tabular}




\section{Conflict of interest statement}

None declared.

\section{Funding sources}

None.

\section{References}

1. Moran F, Bradley JM, Jones AP, Piper AJ. Non-invasive ventilation for cystic fibrosis. Cochrane Database Syst Rev 2009;1. CD002769.

2. Dohna-Schwake C, Podlewski P, Voit T, Mellies U. Non-invasive ventilation reduces respiratory tract infections in children with neuromuscular disorders. Pediatr Pulmonol 2008;43:67-71.

3. Hutchinson GR, Parker S, Pryor JA, et al. Home-use nebulizers: a potential primary source of Burkholderia cepacia and other colistin resistant, gramnegative bacteria in patients with cystic fibrosis. J Clin Microbiol 1996;34: 584-587.

4. Vassal S, Taamma R, Marty N, et al. Microbiologic contamination study of nebulizers after aerosol therapy in patients with cystic fibrosis. Am J Infect Control 2000;28:347-351.

5. O'Malley CA, Van den Branden SL, Zheng XT, Polito AM, McColley SA. A day in the life of a nebulizer: surveillance for bacterial growth in nebulizer equipment of children with cystic fibrosis in the hospital setting. Respir Care 2007;52:258262.

6. Herman A, Kahan Ernesto MD. Bacterial contamination of spacer devices used by asthmatic children. J Asthma 2005;42:169-172.

7. Reychler G, Aarab K, Van Ossel C, et al. In vitro evaluation of efficacy of 5 methods of disinfection on mouthpieces and facemasks contaminated by strains of cystic fibrosis patients. J Cyst Fibros 2005;4:183-187.

8. Vilas Iglesia A, Suares Martinez J. Bronchectasis due to Flavimonas oryzihabitans in an immunocompetent patient. Arch Bronchoneumol 2004;40:384-385. 